\title{
KARAKTERISTIK PERGERAKAN PENUMPANG ANGKUTAN UMUM PERDESAAN DI KABUPATEN KUNINGAN
}

\author{
Adinda Sekar Tanjung \\ Program Studi Perencanaan Wilayah dan Kota \\ Institut Teknologi Sumatera \\ Jln. Terusan Ryacudu, Way Hui \\ Kecamatan Jati Agung \\ Lampung Selatan 33365 \\ sekar.tanjung@pwk.itera.ac.id
}

\author{
Puspita Dirgahayani \\ Sekolah Arsitektur, Perencanaan, dan \\ Pengembangan Kebijakan \\ Institut Teknologi Bandung \\ Jln. Ganesha No. 10, Lb. Siliwangi \\ Kecamatan Coblong, Kota Bandung 40132 \\ puspita.dirgahayani@gmail.com
}

\begin{abstract}
The demand for rural public transportation is dominated by people who cannot access private vehicles. In terms of the number of operating routes and the performance of their services, currently rural public transport services tend to decline. The mobility of rural communities to reach social facilities can be hampered if there is no public transportation service, which in turn will reduce the quality of human resources in rural areas. This study focuses on the movement characteristics of rural public transport passengers in Kuningan Regency. Several rural transportation routes were taken as samples, namely route 030 Cilimus-Linggarjati, route 061 CilimusMandirancan, and route 037 Lengkong-Rancakeusik. This study shows that the characteristics of the movement of rural public transport passengers are an integral part in an effort to maintain rural public transport services. These characteristics of passenger movement can be used to improve the performance of public transportation, become input for public transport operators, and become material for local governments to make policies
\end{abstract}

Keywords: rural public transportation; public transport routes; public transport services; public transport performance.

\begin{abstract}
Abstrak
Permintaan angkutan umum perdesaan didominasi oleh masyarakat yang tidak dapat mengakses kendaraan pribadi. Dari sisi jumlah trayek yang beroperasi dan kinerja layanannya, saat ini layanan angkutan umum perdesaan cenderung semakin menurun. Mobilitas masyarakat perdesaan untuk menjangkau fasilitas sosial dapat terhambat jika tidak ada layanan angkutan umum, yang pada akhirnya akan menurunkan kualitas sumber daya manusia di kawasan perdesaan. Studi ini berfokus pada karakteristik pergerakan penumpang angkutan umum perdesaan di Kabupaten Kuningan. Beberapa trayek angkutan perdesaan diambil sebagai sampel, yaitu trayek 030 Cilimus-Linggarjati, trayek 061 Cilimus-Mandirancan, dan trayek 037 Lengkong-Rancakeusik. Penelitian ini menunjukkan bahwa karakteristik pergerakan penumpang angkutan umum perdesaan merupakan bagian yang tidak terpisahkan dalam upaya mempertahankan layanan angkutan umum perdesaan. Karakteristik pergerakan penumpang ini dapat digunakan untuk meningkatkan kinerja angkutan umum, menjadi masukan bagi operator angkutan umum, serta menjadi bahan pemerintah daerah untuk membuat kebijakan.
\end{abstract}

Kata-kata kunci: angkutan umum perdesaan; trayek angkutan umum; layanan angkutan umum; kinerja angkutan umum.

\section{PENDAHULUAN}

Kawasan perdesaan secara ekonomi dikategorikan sebagai wilayah yang mempunyai kegiatan utama pertanian (Suhardjo, 2008). Munculnya kawasan perdesaan dengan perekonomian yang ditopang oleh kegiatan industri kecil, seperti kerajinan, pariwisata, dan kuliner, 
membuat definisi kawasan perdesaan secara ekonomi tersebut menjadi kurang mewakili keseluruhan tipologi kawasan perdesaan (Roestanto, 2015). Terjadinya perubahan mendasar di semua bidang, sebagai bentuk respons terhadap perubahan sosial, ekonomi, lingkungan, dan politik, menyebabkan kawasan perdesaan tidak lagi sebagai kawasan yang harus didominasi oleh kegiatan pertanian (Illbery, 1998). Kondisi kawasan perdesaan tersebut mempengaruhi aksesibilitas dan karakter pergerakan atau mobilitas masyarakat, baik yang berjalan kaki maupun yang menggunakan kendaraan bermotor, seperti sepeda motor dan angkutan umum (Roestanto, 2015).

Pergerakan masyarakat desa cenderung menuju ke pusat kota, yang dalam hal ini ibu kota kecamatan atau secara keseluruhan terpusat di ibu kota kabupaten, tempat pusat kegiatan ekonomi dan kegiatan sosial berlangsung. Karakteristik pergerakan masyarakat perdesaan dapat dilihat dari maksud perjalanan, frekuensi pergerakan, pemilihan moda, dan jarak perjalanan. Menurut White (2017), penduduk perdesaan adalah penduduk dengan tingkat pendapatan yang rendah dengan kepemilikan kendaraan pribadi yang terbatas. Namun seiring perkembangan ekonomi masyarakat, sepeda motor sudah menjadi barang yang umum dimiliki oleh hampir setiap keluarga di desa. Hal ini menunjukkan kondisi yang berbeda dengan perkembangan layanan transportasi perdesaan di negara sedang berkembang lainnya, yang masih didominasi oleh kendaraan tidak bermotor dan layanan transportasi umum menggunakan bis kecil atau mini van (Dewanti, 2015).

Hasil penelitian Herwangi et al. (2015) di Yogyakarta menunjukkan bahwa masyarakat kurang meminati transportasi umum, karena karakteristik aktivitas, yang terkait dengan lokasi dan fleksibilitas, dan gaya hidup. Kecenderungan saat ini adalah bahwa anak sekolah mulai diberi fasilitas sepeda motor oleh orang tuanya, padahal hal tersebut berdampak negatif pada penurunan keselamatan lalu lintas (Dewanti, 2015). Konsekuensi dari peningkatan jumlah sepeda motor di desa adalah menurunnya jumlah penumpang layanan transportasi umum dan terjadi penurunan kinerja layanan angkutan perdesaan, seperti yang terjadi di Kabupaten Boyolali (Kurniawan, 2005), di Kabupaten Jember (Siswanto, 2013), serta di Kabupaten Klaten (Dewanti, 2015).

Walaupun layanan angkutan perdesaan di beberapa wilayah di Indonesia mulai mengalami penurunan kinerja layanan dan penurunan trayek yang operasional, namun angkutan tersebut masih dibutuhkan oleh masyarakat golongan paksawan, yaitu masyarakat yang tidak dapat mengakses kendaraan pribadi. Masyarakat ini merupakan pasar angkutan perdesaan, yang didominasi oleh anak sekolah, orang tua atau lansia, ibu rumah tangga, dan sedikit kelompok usia pekerja (White, 2017; Kurniawan, 2005). Mobilitas masyarakat tersebut untuk menjangkau fasilitas-fasilitas pendidikan, kesehatan, dan ekonomi akan terhambat jika tidak ada layanan angkutan umum, sehingga akan menurunkan kualitas sumber daya manusia di kawasan perdesaan juga.

Secara teoritis frekuensi pergerakan masyarakat desa tidak sama dengan frekuensi pergerakan masyarakat perkotaan, namun pergerakan, sebagai kebutuhan turunan, harus tetap terwadahi di perdesaan. Jangan sampai angkutan umum menjadi punah dan masyarakat terpaksa memiliki kendaraan pribadi, padahal ada masyarakat rentan yang masih membutuh- 
kan layanan angkutan umum. Pemangku kebijakan harus mengetahui kondisi masyarakat ini, sehingga dapat mengambil kebijakan angkutan umum ini dengan benar, karena ketika angkutan umum perdesaan dengan trayek resmi sudah tidak beroperasi, akan muncul kendaraan-kendaraan pribadi yang dikomersilkan untuk mewadahi mobilitas masyarakat.

Dalam menyikapi beberapa kondisi yang telah dijelaskan sebelumnya, studi ini terlebih dahulu difokuskan pada pengguna angkutan umum perdesaan, sebelum melakukan intervensi terhadap upaya peningkatan kinerja angkutan umumnya. Oleh karena itu, penelitian ini bertujuan untuk menganalisis karakteristik pergerakan penumpang angkutan umum perdesaan.

Dengan mengambil karakteristik layanan angkutan umum di kawasan perdesaan yang bernuansa agraris dan campuran karena pegaruh pariwisata, studi ini dilakukan di Kabupaten Kuningan. Batasan penelitian ini adalah pada penumpang angkutan umum perdesaan trayek 030 Cilimus-Linggarjati, trayek 061 Cilimus-Mandirancan, dan trayek 037 Lengkong-Rancakeusik, yang dipilih berdasarkan beberapa kriteria tertentu, sehingga trayek-trayek tersebut mewakili kondisi perdesaan di Kabupaten Kuningan. Manfaat penelitian ini secara praktis adalah memberikan masukan kepada pemerintah daerah tentang kebijakan layanan angkutan umum dan manfaat secara teoritis adalah memperkaya pengetahuan tentang pergerakan masyarakat perdesaan yang menggunakan angkutan umum.

Penelitian ini menggunakan pendekatan kuantitatif, dengan menggunakan data primer yang diperoleh melalui kuesioner dan observasi. Data kuesioner dilakukan untuk mengetahui karakteristik perjalanan penumpang yang dilakukan selama seminggu, sedangkan observasi dilakukan untuk mengetahui titik-titik asal dan tujuan penumpang, serta titik permintaan penumpang. Observasi dilakukan pada hari kerja dan pada akhir pekan. Populasi yang digunakan pada penelitian ini adalah total jumlah penumpang angkutan perdesaan trayek-trayek 030, 061, dan 037 dalam satu hari, yang merupakan hasil survei statis. Instrumen penelitian yang digunakan berupa form kuesioner, form observasi, kamera, dan GPS. Metode analisis yang digunakan dalam penelitian ini adalah analisis deskriptif kuantitatif.

\section{HASIL DAN PEMBAHASAN}

\section{Wilayah Layanan Angkutan Umum Perdesaan}

Angkutan umum perdesaan atau angdes trayek 030 Cilimus-Linggarjati melewati 7 wilayah administrasi desa, yakni Desa Cilimus, Desa Bojong, Desa Bandorasa Wetan, Desa Bandorasa Kulon, Desa Linggasana, Desa Linggarjati, dan Desa Setianegara, dengan panjang lintasan sekitar $6 \mathrm{~km}$. Trayek Angdes 030 Cilimus-Linggarjati ini melewati kawasan perdesaan dengan kepadatan rata-rata 22 jiwa/Ha. Penggunaan lahan kawasan perdesaan yang dilewati oleh Trayek Angdes 030 Cilimus-Linggarjati, secara administratif, menunjukkan proporsi luas lahan pertanian sekitar 54\% terhadap total luas wilayahnya. Berdasarkan data guna lahan terbaru, sepanjang koridor angkutan umum memiliki potensi 
bangkitan dan tarikan yang cukup tinggi, karena melewati kawasan perdagangan dan jasa, fasilitas pendidikan, pariwisata, permukiman padat. Jumlah armada angdes 030 yang beroperasi saat ini adalah 44 armada, berdasarkan hasil survei statis di Terminal Cilimus.

Angdes Trayek 061 Cilimus-Mandirancan memiliki jarak lintasan sekitar 9 km, dengan melewati 10 wilayah administrasi desa, yaitu Desa Cilimus, Desa Caracas, Desa Sampora, Desa Silebu, Desa Pakembangan, Desa Kahiyangan, Desa Randobawailir, Desa Tajurbuntu, Desa Mandirancan, dan Desa Sukasari. Sekitar 64\% lahan di kawasan perdesaan yang dilewati oleh Trayek Angdes 061 adalah lahan pertanian. Berdasarkan data guna lahan terbaru di sepanjang koridor, diketahui bahwa lebih banyak lahan sawah dan permukiman kepadatan rendah, sehingga bangkitan penumpang tidak banyak, serta pusat keramaian berada di titik asal dan di titik tujuan akhir. Trayek angkutan perdesaan 061 CilimusMandirancan melewati kawasan perdesaan dengan kepadatan 18 jiwa/Ha.

Trayek 037 Lengkong-Rancakeusik saat ini merupakan gabungan dari 2 trayek lain yang memiliki lintasan yang sama, yaitu trayek 038, Lengkong-Rancakeusik via Langseb, dan trayek 039, Lengkong-Luragung via Maleber. Sekitar 58\% lahan kawasan perdesaan yang dilewati oleh Trayek Angdes 037 Lengkong-Rancakeusik adalah lahan pertaian. Penggunaan lahan di sepanjang koridor menunjukkan bahwa layanan angdes ini melewati kawasan perdesaan dengan kegiatan yang sudah bersifat campuran antara pertanian serta perdagangan dan jasa. Berdasarkan guna lahan terbaru di sepanjang koridor diketahui bahwa fasilitas perdagangan dan jasa serta pendidikan cukup lengkap, melewati permukiman padat, namun masih melewati persawahan di 3 desa. Jalur trayek angdes Lengkong-Rancakeusik melewati kawasan perdesaan dengan kepadatan rata-rata 20 jiwa/Ha.

\section{Karakteristik Pergerakan Penumpang}

Karakteristik pergerakan penumpang angkutan perdesaan ini akan menggambarkan karakter penumpang yang terdiri atas anak sekolah, ibu rumah tangga, pekerja, dan pedagang, frekuensi penggunaan, tujuan perjalanan, dan waktu pergerakan. Karakteristik penumpang ini diperoleh dari kuesioner terhadap penumpang. Karakteristik penumpang pada trayek-trayek 030, 061, dan 037 menunjukkan kesamaan, yakni didominasi oleh kaum wanita dan anak sekolah SMP, SMA, dan SMK. Kondisi ini mencirikan pengguna angkutan perdesaan di negara sedang berkembang, yang mana pelaku perjalanan didominasi oleh kaum wanita dan penumpang usia produktif. Ciri ini berbeda dengan angkutan umum di negara maju, yang lebih berperan untuk mobilitas masyarakat lanjut usia.

Tujuan perjalanan dengan angkutan umum memperlihatkan potensi tarikan fasilitas yang terletak di sepanjang koridor trayek angkutan perdesaan. Berdasarkan hasil kuesioner terhadap rumah tangga pengguna angkutan umum, diperoleh data tujuan perjalanan dengan angkutan perdesaan, yang meliputi sekolah (mayoritas), pasar (mayoritas), fasilitas kesehatan (mayoritas), dan bekerja (minoritas). Mayoritas yang dimaksud di sini adalah banyak penumpang yang menggunakan angkutan perdesaan dengan tujuan tersebut, tetapi tidak selalu memiliki frekuensi penggunaan paling banyak. Frekuensi penggunaan angkutan perdesaan di wilayah studi ini dibedakan menjadi penggunaan rutin (mingguan) dan 
penggunaan tidak rutin. Penggunaan rutin (mingguan) dilakukan oleh anak sekolah, pedagang, pekerja, dan ibu rumah tangga yang mengantarkan anaknya ke sekolah (5-6) kali seminggu atau (2-3) kali seminggu. Penggunaan tidak rutin dilakukan oleh ibu rumah tangga dan masyarakat umum lainnya (1-2) kali sebulan atau insidental.

Dengan karakter pergerakan masyarakat desa yang melakukan pergerakan eksternal cukup minim (Rahardjo, 2008), frekuensi penggunaan angkutan umum di wilayah studi juga terlalu timpang antara pengguna rutin dan pengguna tidak rutin, seperti yang ditunjukkan pada Gambar 1.

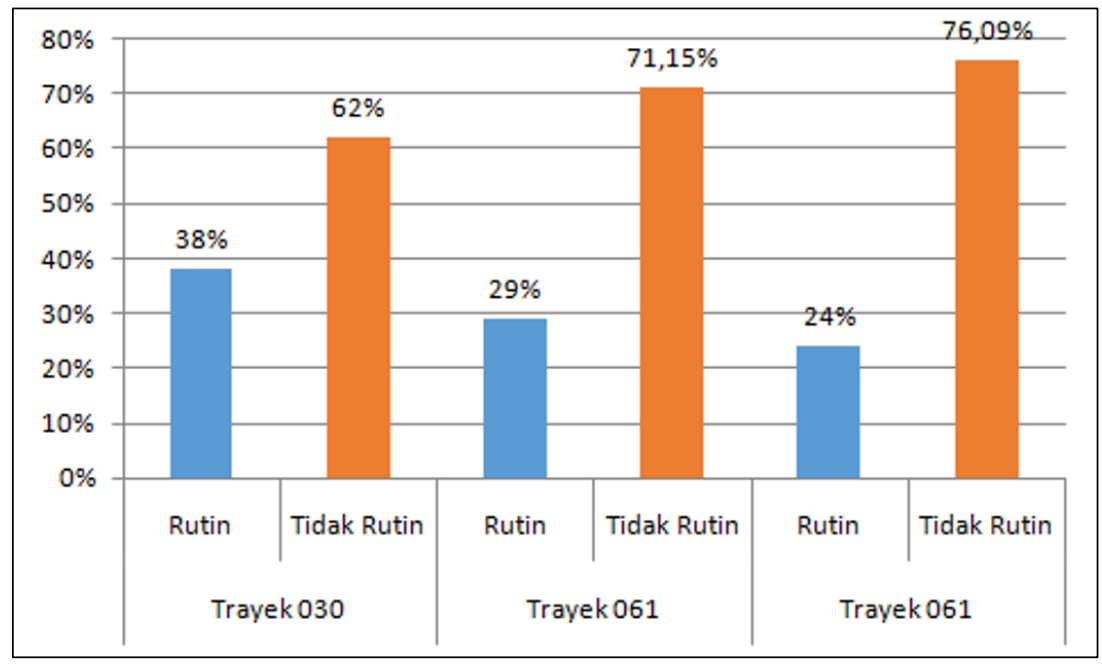

Gambar 1 Frekuensi Penggunaan Angkutan Perdesaan di Wilayah Studi

Pengguna tidak rutin adalah penumpang yang menggunakan angkutan perdesaan cukup jarang, yaitu hanya (1-2) kali sebulan, dengan maksud perjalanan ke pasar dan perjalanan insidental atau tiba-tiba, seperti perjalanan ke puskesmas atau rumah sakit dan mengunjungi saudara. Tujuan dan frekuensi penggunaan angkutan perdesaan di wilayah studi dalam sebulan dapat dilihat pada Gambar 2.

Gambar 2 menunjukkan bahwa penggunaan angkutan perdesaan oleh ibu rumah tangga banyak digunakan untuk maksud perjalanan ke pasar, namun dengan frekuensi yang cukup rendah, karena dilakukan sekitar sekali sebulan. Hal ini dikarenakan di masingmasing desa sudah ada pedagang sayur, sehingga ke pasar desa dilakukan untuk membeli barang yang tidak dijual oleh pedagang sayur di desa. Untuk penumpang trayek 037, pasar yang dimaksud adalah Pasar Baru Kuningan, yang terletak di pusat kota, sehingga masyarakat yang menggunakan angdes trayek 037 ini harus berganti angkutan trayek 07 Lengkong-Pasar Baru. Sedangkan untuk perjalanan ke pasar yang ada di Kecamatan Garawangi maupun pasar yang ada di Kecamatan Maleber lebih banyak dilakukan dengan berjalan kaki.

Biasanya pedagang kelontong yang menggunakan angkutan umum untuk ke pasar, dengan frekuensi 4 kali atau lebih dari 4 kali dalam sebulan. Selebihnya, penggunaan angkutan perdesaan ini dilakukan dengan maksud mengantar anak ke sekolah, ke puskesmas, 
dan sebagian ke tempat bekerja. Untuk maksud perjalanan ke puskesmas juga jarang dilakukan, karena waktu sakit seseorang tidak dapat diprediksi.
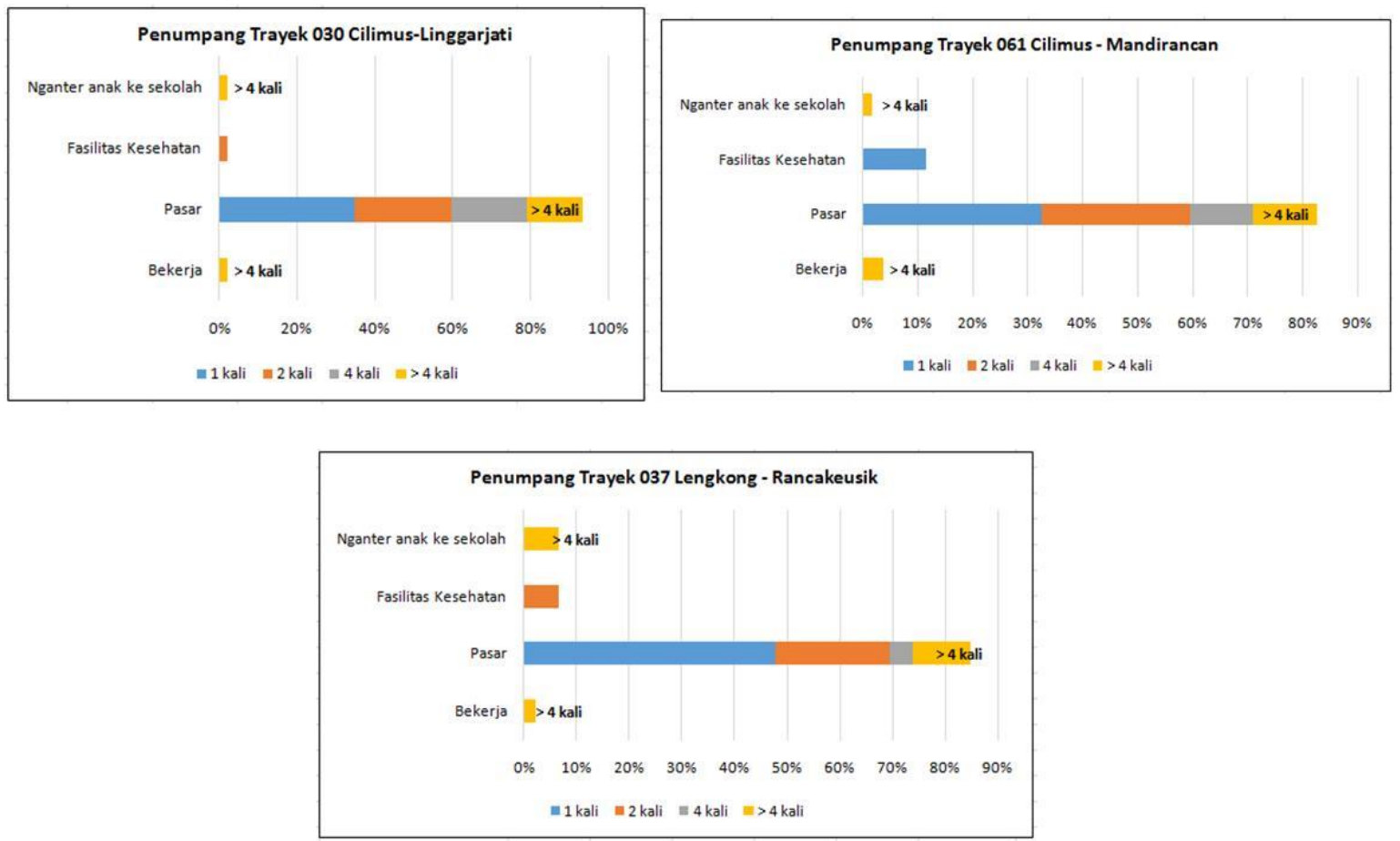

Gambar 2 Tujuan dan Frekuensi Perjalanan Penumpang Angkutan Perdesaan dalam 1 Bulan

Gambar 3 menunjukkan asal-tujuan penumpang, baik pelajar maupun ibu rumah tangga, yang menggunakan angkutan umum dalam sehari, yang diperoleh dari hasil kuesioner rumah tangga. Ketebalan garis panah menunjukkan jumlah responden sesuai dengan struktur keluarga yang menggunakan angkutan umum.
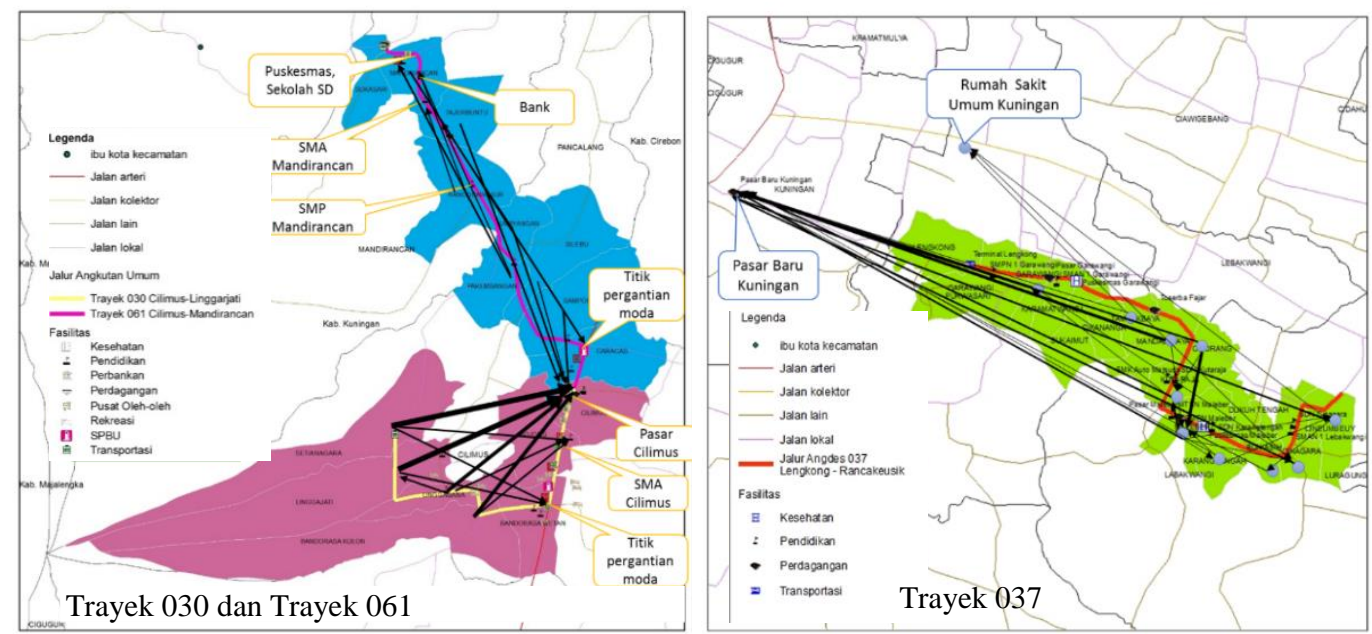

Gambar 3 Ilustrasi Asal-Tujuan Pergerakan Penumpang 
Untuk penumpang trayek 030, pergerakan internal masyarakat dalam wilayah desa yang menggunakan angkutan umum sangat jarang ditemukan. Pergerakan penumpang di wilayah studi, khususnya ibu rumah tangga, cenderung bertujuan ke Pasar Cilimus, yang merupakan wilayah pusat kecamatan. Di Desa Linggarjati terdapat beberapa hotel, sehingga terdapat juga warga yang menggunakan angkutan umum dengan maksud bekerja. Fasilitas kesehatan dan pendidikan kelas menengah atas berada di jalur utama, yang merupakan jalan provinsi, sehingga masyarakat melakukan pergerakan keluar dari kawasan permukiman di desa. Berbeda dengan karakteristik pergerakan penumpang di jalur Cilimus-Mandirancan yang menghubungkan 2 pusat aktivitas, yaitu Pasar Cilimus dan Pusat Kecamatan Mandirancan. Pergerakan internal dalam jalur angkutan umum terlihat dari keberadaan fasilitas pendidikan skala menengah dan skala mengenah atas yang menjadi tujuan para siswa atausiswi sekolah. Berdasarkan informasi dari perangkat desa, pergerakan masyarakat cenderung ke Kecamatan Sumber, Kabupaten Cirebon, dibandingkan dengan ke pusat Kota Kuningan.

Pola pergerakan masyarakat yang menggunakan angkutan umum perdesaan 037 ratarata menuju ke Pasar Baru Kuningan, dengan melakukan perpindahan 1 kali di Terminal Lengkong. Pergerakan yang menuju RS Kuningan biasanya melakukan perpindahan angkutan umum lagi di Winduhaji. Sebaran fasilitas yang cukup lengkap di sepanjang jalur angkutan umum tersebut membuat adanya pergerakan-pergerakan internal kecamatan di dalamnya, khususnya pergerakan yang dilakukan oleh pelajar. Pergerakan internal kecamatan biasanya dengan maksud untuk berbelanja, urusan perbankan, dan berobat ke puskesmas.

Hari pasaran juga mempengaruhi masyarakat dalam melakukan perjalanan ke pasar. Berikut disajikan pasar-pasar yang mempunyai hari pasaran per minggu di wilayah studi:

a) Pasar Cilimus memiliki hari pasaran hari Minggu, sehingga pada hari Minggu pasar ini ramai dikunjungi keluarga, yan terdiri atas suami, istri, anak, atau beserta orang tua.

b) Pasar Maleber memiliki hari pasaran hari Jumat, sehingga pada hari Jumat pasar ini ramai dikunjungi ibu-ibu rumah tangga dan moda angkutan umum di pasar ini bertambah dengan keberadaan andong, becak, dan motor roda tiga.

c) Pasar Garawangi memiliki hari pasaran hari Senin, sehingga pada hari Senin pasar ini ramai dikunjungi ibu-ibu rumah tangga, sedangkan moda angkutan umum di pasar ini ketika hari pasaran tidak sebanyak moda angkutan umum di Pasar Maleber.

d) Pasar Baru Kuningan memiliki hari pasaran hari Senin dan Kamis, sehingga pada kedua hari tersebut pasar ramai dikunjungi oleh masyarakat dari berbagai desa untuk menjual dan membeli barang-barang dagangan.

Berdasarkan hasil kuesioner diketahui karakteristik perjalanan masyarakat dengan menggunakan angkutan umum dari segi waktu. Titik asal perjalanan masyarakat yang menggunakan angdes Trayek 030 adalah rumah, dan titik asal perjalanan pulang adalah Pasar Cilimus. Pergerakan penumpang trayek 030 ke pasar dimulai pada pagi hari, dari pukul 06.00 hingga pukul 09.00. Rata-rata masyarakat kembali ke rumah pada rentang waktu pukul 10.00 hingga pukul 13.00. Waktu pergerakan penumpang trayek 061 tidak jauh berbeda 
dengan waktu pergerakan penumpang trayek 030. Masyarakat lebih banyak melakukan aktivitas dengan angkutan umum di pagi hari, pada rentang waktu pukul 07.00 hingga pukul 10.00, dengan mayoritas tujuan pergerakan adalah Pasar Cilimus. Pada siang hari masyarakat jarang keluar rumah, selain karena menunggu kendaraannya lebih lama, juga karena aktivitas masyarakat juga terbatas. Tidak ada tujuan lain yang membuat mereka keluar rumah selain mengunjungi saudara jika memiliki saudara di desa lain dan itupun jarang dilakukan.

Penumpang trayek 037 juga memiliki karakteristik waktu yang serupa, yaitu masyarakat lebih banyak melakukan aktivitas dengan angkutan umum di pagi hari dan di siang hari untuk kembali pulang ke rumah. Pukul 08.00 merupakan waktu yang paling banyak dipilih masyarakat untuk keluar rumah dan pukul 12.00 merupakan waktu yang banyak dipilih masyarakat untuk kembali ke rumah. Perjalanan masyarakat yang ke Pasar Baru rata-rata menggunakan 2 kali moda angkutan umum. Waktu pergerakan anak sekolah di masing-masing trayek menunjukkan karakter yang sama, yaitu waktu berangkat adalah sekitar pukul 06.30 hingga pukul 07.00 dan waktu pulang sekitar pukul 15.00-16.00. Waktu pergerakan pedagang, yang biasanya mengangkut banyak barang, di masing-masing trayek menunjukkan karakter yang sama, yaitu waktu pulang sekitar pukul 06.00. Waktu pergerakan penumpang umum pada trayek 030 ini banyak dilakukan pada pukul 08.0009.00, dan pada rute ini masih terlihat penumpang pada siang hari yang menuju ke pasar. Sedangkan waktu pulang penumpang cukup bervariasi, namun yang paling tinggi adalah pukul 10.00 .

Waktu pergerakan penumpang umum pada trayek 061 banyak dilakukan pada pukul 07.00-08.00, sedangkan waktu pulang cukup bervariasi, namun yang paling tinggi adalah pukul 10.00. Waktu pergerakan penumpang umum pada trayek 037 banyak dilakukan pada pukul 07.00-08.00, sedangkan waktu pulang cukup bervariasi, namun yang paling tinggi adalah pukul 12.00. Waktu pulang penumpang trayek 037 lebih siang dibandingkan dengan waktu pulang di 2 trayek lainnya, karena menggunakan angkot 07 terlebih dahulu sebelum berganti moda dengan angdes 037 .

\section{Implikasi Karakteristik Penumpang terhadap Layanan Angkutan Perdesaan}

Karakteristik penumpang angkutan perdesaan trayek 030 Cilmus-Linggarjati, trayek 060 Cilimus-Mandirancan, dan trayek Lengkong-Rancakeusik dapat menjadi bahan pertimbangan evaluasi kinerja layanan angkutan umum. Jumlah armada yang beroperasi di masing-masing trayek sudah melebihi batas jumlah armada yang dikeluarkan oleh Dinas Perhubungan Kabupaten Kuningan. Dengan kondisi pengguna angkutan umum yang hanya dari golongan paksawan, diperlukan efisiensi jumlah armada yang beroperasi. Hal ini dimaksudkan agar armada yang beroperasi dapat memperoleh pendapatan yang optimal.

Kawasan perdesaan tidak memerlukan jadwal dan rute yang tetap, karena dengan kondisi kepadatan yang rendah, layanan angkutan umum dapat lebih fleksibel (Saeed dan Kuraichi, 2015). Jadwal layanan angkutan umum perdesaan di wilayah studi dapat fleksibel mengikuti karakteristik waktu pergerakan penumpang, dan operasional angkutan perdesaan mengikuti waktu pergerakan masyarakat dari pagi hingga sore hari. Hal ini akan berkaitan 
juga dengan frekuensi serta waktu antara angkutan umum. Dalam durasi waktu operasional tersebut, terdapat waktu-waktu tertentu dengan frekuensi kendaraan yang lebih sering dan pada waktu-waktu yang lain angkutan umum memiliki waktu antara 30 menit hingga 1 jam. Hal-hal seperti ini harus terinformasi ke penumpang, sehingga ketika akan bepergiaan masyarakat yakin bahwa akan ada angkutan umum yang melintas.

Dengan mengetahui karakteristik waktu pergerakan masyarakat, operator dapat mengatur frekuensi dan waktu antara armada kendaraan dan meminimalisir kecilnya kapasitas penumpang per kendaraannya. Frekuensi armada angkutan umum disarankan untuk disesuaikan dengan waktu ketika permintaan akan angkutan tinggi.

Dalam menutupi Biaya Operasi Kendaraan (BOK), operator angkutan umum bergantung pada jumlah penumpang. Karakteristik pergerakan penumpang ini cukup memberikan gambaran bahwa BOK angkutan umum perdesaan ini lambat laun tidak tertutupi jika tidak ada subsidi dari pemerintah daerah. Angkutan umum perdesaan saat ini sudah seperti layanan bus sekolah bagi pelajar, sehingga dalam rangka memberikan layanan transportasi yang memadai bagi generasi penerus bangsa, hal ini dapat menjadi pertimbangan pemerintah daerah untuk memperhatikan angkutan umum perdesaan ini.

Studi ini menunjukkan bahwa bahwa sebagian penumpang membawa barang yang cukup banyak banyak, baik menuju ke pasar maupun pulang dari pasar. Oleh karena itu, diperlukan spesifikasi armada angkutan umum yang sesuai dengan kondisi masyarakat perdesaan, dan bukan sekedar mengadopsi sepenuhnya dari angkutan perkotaan.

\section{KESIMPULAN}

Karakteristik pergerakan penumpang angkutan umum perdesaan, yang meliputi karakter penumpang, frekuensi penggunaan, tujuan perjalanan, dan waktu pergerakan menjadi bagian yang tidak terpisahkan dalam upaya mempertahankan permintaan angkutan umum saat ini. Karakteristik pergerakan penumpang ini memberikan implikasi pada beberapa kinerja layanan angkutan umum, seperti jumlah armada yang beroperasi, jadwal layanan, frekuensi dan waktu antara, BOK, dan spesifikasi armada. Karakteristik pergerakan penumpang ini dapat menjadi masukan bagi operator dalam menyediakan layanan angkutan umum serta menjadi masukan bagi pemerintah daerah dalam menetapkan kebijakan, untuk evaluasi, maupun untuk memberikan subsidi.

\section{DAFTAR PUSTAKA}

Dewanti. 2015. Pola Perkembangan Layanan Transportasi Perdesaan Studi Kasus Wilayah Datar dan Berbukit. Disertasi tidak diterbitkan. Program Pascasarjana. Yogyakarta: Universitas Gadjah Mada.

Herwangi, Y., Pradono, P. Syabri, I., dan Kustiwan, I. 2015. Peran dan Pola Penggunaan Sepeda Motor pada Masyarakat Berpendapatan Rendah di Kawasan Perkotaan Yogyakarta. Jurnal Perencanaan Wilayah dan Kota, 26 (3): 166-176. 
Illbery, B. 1998. The Geography of Rural Change. London: Longman.

Kurniawan, Z. 2005. Fenomena Angkutan Desa-Kota di Kabupaten Boyolali. Tesis tidak diterbitkan. Program Magister Perencanaan Wilayah dan Kota. Semarang: Universitas Diponegoro.

Rahardjo, A. 2008. Pengembangan Wilayah Konsep dan Teori. Yogyakarta: Graha Ilmu.

Roestanto, W.D. 2015. Membangun Perdesaan Modern: Tata Kelola Infrastruktur Desa. Bogor: Indodata Development Center.

Saeed, K. dan Kurauchi, F. 2015. Enhancing the Service Quality of Transit Systems in Rural Areas by Flexible Transport Services. Transportation Research Procedia, 10: 514-523.

Siswanto, D. 2013. Faktor-Faktor yang Mempengaruhi Pendapatan Sopir Angkutan Pedesaan Terminal Arjasa Kabupaten Jember. Tugas Akhir tidak diterbitkan. Program Sarjana Ilmu Ekonomi dan Studi Pembangunan, Fakultas Ekonomi. Jember: Universitas Jember.

Suhardjo, A.J., Baiquni, M., Rijanta, R., dan Kurniawan, A. 2008. Geografi Perdesaan, Sebuah Antologi. Yogyakarta: IdeAs Media.

White, P.R. 2017. Public Transport: Its Planning, Management and Operations. Sixth Edition. London: Tayor and Francis. 